\title{
Genetic Diversity and Structure in the Philippine Rafflesia lagascae Complex (Rafflesiaceae) inform its Taxonomic Delimitation and Conservation
}

\author{
Pieter B. Pelser, ${ }^{1,4}$ Daniel L. Nickrent, ${ }^{2}$ Chrissen E. C. Gemmill, ${ }^{3}$ and Julie F. Barcelona ${ }^{1}$ \\ ${ }^{1}$ School of Biological Sciences, University of Canterbury, Private Bag 4800, Christchurch 8140, New Zealand \\ ${ }^{2}$ Department of Plant Biology, Southern Illinois University Carbondale, 1125 Lincoln Drive, Carbondale, \\ Illinois 62901-6509, U. S. A. \\ ${ }^{3}$ School of Science, University of Waikato, Private Bag 3105, Hamilton 3240, New Zealand \\ ${ }^{4}$ Author for correspondence (pieter.pelser@canterbury.ac.nz)
}

\section{Communicating Editor: Sasa Stefanovic}

\begin{abstract}
Rafflesia lagascae is a rare endo-holoparasitic species with a disjunct distribution on Luzon Island. It is morphologically very similar to $R$. manillana from nearby Samar. This study aims to contribute to the taxonomy and conservation of $R$. lagascae and $R$. manillana (i.e. the $R$. lagascae complex) by resolving their patterns of genetic diversity and structure. The results of analyses of a microsatellite data set indicate that despite their frequently extremely small sizes and geographic isolation, Rafflesia populations display moderate genetic diversity and do not show evidence of pronounced inbreeding. Most populations appear to have limited gene flow among them. Patterns of genetic diversity of staminate and pistillate Rafflesia flowers growing on the same Tetrastigma host plants indicate that the $R$. lagascae complex is monoecious and that host plants are regularly infected by multiple Rafflesia plants. PCoA and Bayesian cluster analyses show that the complex is composed of three genetically isolated taxa. One of these constitutes R. manillana, supporting the morphology-based hypothesis that it is taxonomically distinct from $R$. lagascae. The second taxon in this complex is composed of a morphologically cryptic $R$. lagascae population from Mt. Labo, which is genetically distinct from all remaining $R$. lagascae populations that were studied and that form the third taxon. We recommend that these three taxa are managed as different conservation entities.
\end{abstract}

Keywords—Microsatellites, parasitic plants, rare species, species complex, taxonomy.

The host species of parasitic plants form essential components of their environment (Sandner and Matthies 2017). Their distribution patterns constitute the maximum potential distribution area of the parasitic plant species that depend on them for their existence (Costea and Stefanović 2009) in the same way that specialists of a rare habitat are confined to areas where this habitat is found (e.g. Medrano and Herrera 2008; Williams et al. 2016) and the distribution of elevation specialists is constrained by topography (e.g. Laurance et al. 2011). When the prerequisite conditions on which specialist plant species depend are rare, so are these species. Consequently, some specialist plants have small population sizes and are restricted to a single small area (e.g. de Lange 2003) or have a disjunct distribution pattern (e.g. Medrano and Herrera 2008). This makes these species vulnerable to inbreeding and genetic drift as a result of a loss of genetic connectivity between populations due to habitat fragmentation and degradation (e.g. Ellstrand and Elam 1993; Schmidt and Jensen 2000; Stanton et al. 2009; Williams et al. 2016). This might ultimately result in a loss of genetic diversity and thereby increase the probability that small and isolated populations go extinct (Schmidt and Jensen 2000). Indeed, many parasitic plant species are rare and listed as threatened or endangered (Marvier and Smith 1997; Sandner and Matthies 2017). Parasitic species that are very host specific are especially at risk, because they are particularly sensitive to changes in host availability and typically have small distribution areas (Costea and Stefanović 2009).

Rafflesia R.Br. (Rafflesiaceae) is a Southeast Asian plant genus of ca. 36 species (Hidayati and Walck 2016), all of which are obligate endo-holoparasites of Tetrastigma (Miq.) Planch. (Vitaceae; Meijer 1997; Nais 2001; Pelser et al. 2016). The Philippines is one of the centers of Rafflesia diversity (Barcelona et al. 2009) and is home to 13 currently recognized species (Pelser et al. 2011 onwards; Barcelona et al. 2014; Galindon et al. 2016), which are all endemic to the country. Rafflesia lagascae Blanco (1845) is arguably the most common Rafflesia species in the Philippines and has the largest distributional area (Barcelona et al. 2009). However, although it can be found throughout the island of Luzon (Fig. 1), it has a highly disjunct distribution and is only known from 15 small areas. In some of these areas, it is only known from one or a few individual host plants belonging to three species of Tetrastigma (Pelser et al. 2016). Because of the small number of $R$. lagascae populations and the extremely small size of many of them, as well as its narrow host range, this species might be particularly prone to genetic diversity loss following habitat fragmentation and degradation. This is potentially a significant conservation factor, because the Philippine tropical rainforest, to which this species is confined, has been reduced to an estimated 3-6\% of its original cover (Mittermeier et al. 1998; Ong et al. 2002). Moreover, remaining tropical forest habitat has become highly degraded and fragmented as a result of human activities such as logging, mining, and land conversion for agriculture (Barcelona et al. 2009). To better understand the conservation needs of $R$. lagascae and to improve its management, information about its patterns of genetic diversity and genetic structure are needed. These patterns would, for instance, enable the identification of the populations that have the lowest genetic diversity and least genetic connectivity with other populations and that are therefore most at risk of inbreeding and genetic drift.

At present, nothing is known about patterns of genetic diversity and structure in any Rafflesia species. Previous molecular genetic studies of Rafflesia have focused on horizontal gene transfer from their hosts (Davis and Wurdack 2004; Nickrent et al. 2004; Xi et al. 2012, 2013), their evolutionary relationships and diversification (Barkman et al. 2004, 2008; Nickrent et al. 2004; Davis et al. 2007; Bendiksby et al. 2010), the molecular regulation of flower development (Nikolov et al. 2013; Ramamoorthy et al. 2013), and the possible loss of their chloroplast genome (Molina et al. 2014), but none have addressed research questions at the infraspecific level. Because of the absence of molecular genetic data for Rafflesia at the levels of individuals and populations, not only are their patterns of genetic diversity and genetic structure unknown, but 


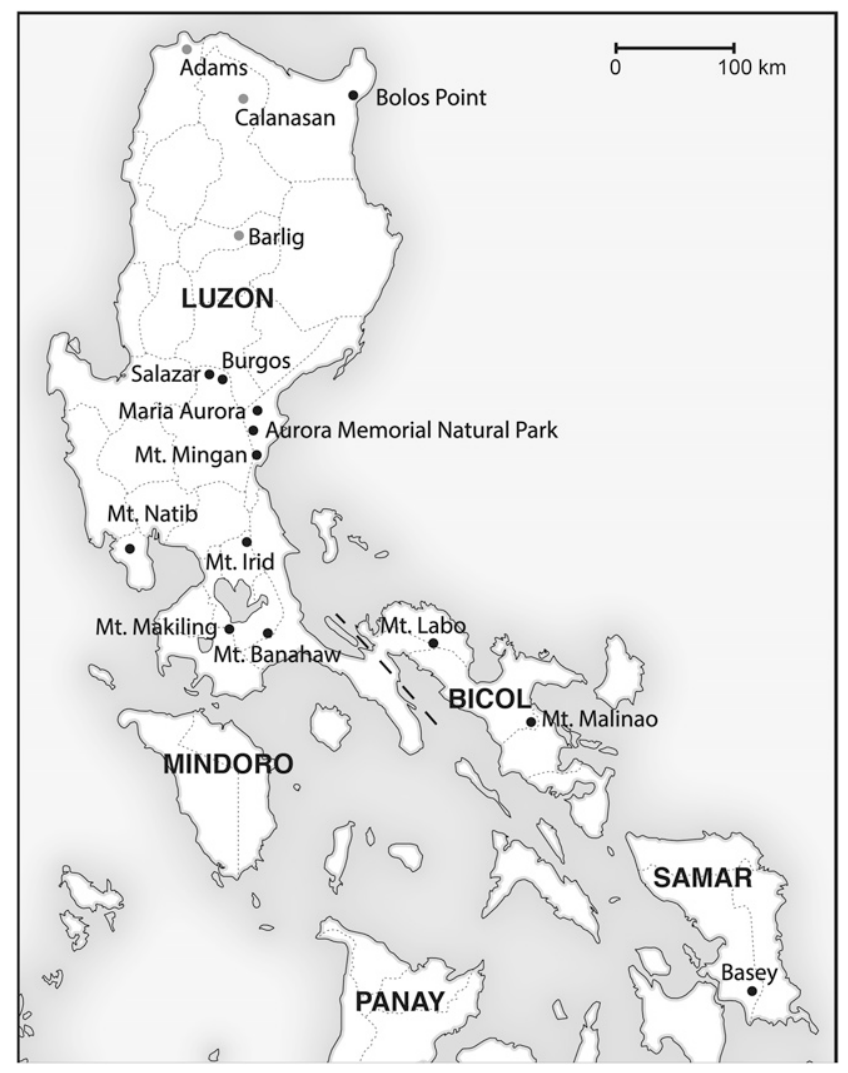

FIG. 1. Distribution of all currently known populations of R. lagascae and R. manillana. Black dots indicate populations that were sampled for this study. Grey dots are populations that could not be sampled. The dotted line indicates the approximate position of the Guinyangan fault (Besana and Ando 2005) and marks the area where the Bicol Peninsula connects with mainland Luzon. Faint dotted lines indicate provincial boundaries.

other aspects of their biology also remain to be discovered. For example, most Rafflesia species, including $R$. lagascae, have unisexual flowers, but it is not known if they are dioecious or monoecious (Nais 2001). It is difficult to determine plant sexuality without genetic data, because of their endoparasitic nature (Balete et al. 2010). In other words, it is not possible to determine if staminate and pistillate flowers that emerge from the same host belong to the same genetically identical individual endophyte. Because self-incompatible plants might be more vulnerable to a loss of genetic diversity resulting from habitat fragmentation (Stanton et al. 2009), knowing if
$R$. lagascae is monoecious or dioecious is relevant for its conservation management. Similarly, it is presently unclear if Tetrastigma vines can be host to more than one Rafflesia individual. This basic information about Rafflesia will enable more accurate estimates of population sizes and thereby contribute to their conservation management.

Population-level genetic data are also needed to inform the taxonomic delimitation of $R$. lagascae. This species is morphologically very similar to $R$. manillana Teschem. (Teschemacher 1844; Fig. 2) and both taxa were considered synonymous until relatively recently (Madulid et al. 2008; Pelser et al. 2013). Whereas R. lagascae is endemic to Luzon, R. manillana has only been reported from Basey municipality on Samar Island. The two allopatric species are of similar sizes (11-24 vs. 11-16 cm diam; Madulid and Agoo 2008; Barcelona et al. 2009) and primarily differ in the color of the floral diaphragm and the relative size of the diaphragm aperture (Pelser et al. 2013; Fig. 2), but it is presently unclear if these morphological differences are indicative of species level genetic differences. Rafflesia manillana is currently only known from a single population and is considered critically endangered by Madulid and Agoo (2008). Therefore, if despite their morphological differences both taxa are genetically indistinct, the conservation status of $R$. manillana would need to be revised.

In this study, we provide the first examination of the patterns of genetic diversity and genetic structure of $R$. lagascae and $R$. manillana (from here on collectively referred to as the $R$. lagascae complex). Specifically, we aim 1) to identify populations that have low genetic diversity, 2) to determine if taxa in the $R$. lagascae complex are monoecious or dioecious and if Tetrastigma plants can host more than one Rafflesia individual, and 3) to resolve the taxonomic delimitation of the R. lagascae complex.

\section{Materials And Methods}

Specimen Sampling-Tissue samples on silica gel and voucher specimens preserved in $70 \%$ denatured alcohol were collected from 13 of the 16 areas from which members of the $R$. lagascae complex have been reported. For the three unsampled areas (Adams, Ilocos Norte Prov.; Barlig, Mountain Prov.; Calanasan, Apayao Prov.; Fig. 1), collecting permits or samples could not be secured in time for this study. Tissue was taken from at least one flower or flower bud from each infected host plant that was encountered, with a maximum of six samples taken per site (i.e. one or more infected host plants in close vicinity of each other and geographically isolated from other such sites). Nearby host plants were considered distinct individuals if they were unambiguously spatially separated from each
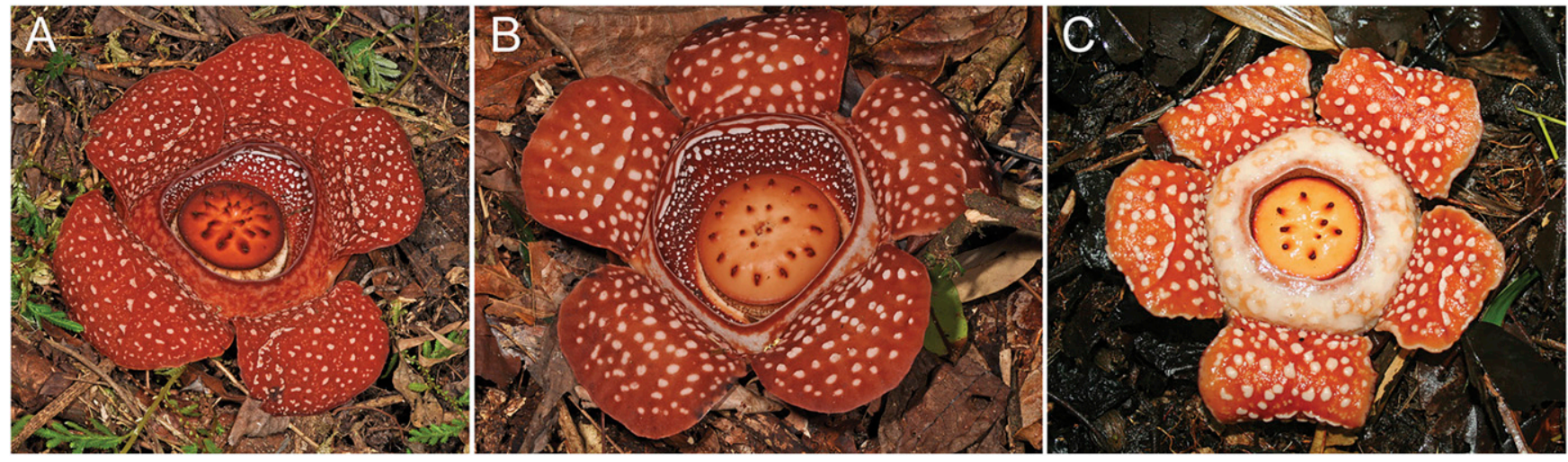

Fig. 2. Flowers of the three Rafflesia taxa identified in this study. A. R. lagascae s. s. B. Mt. Labo R. lagascae. C. R. manillana. 
other. When possible, damage to Rafflesia plants was minimized by removing a small amount of tissue from the diaphragm or the perigone lobes of the flowers, which is not expected to affect their reproductive function. When flower buds were encountered, we sampled tissue from the perigone lobes or disk of young flower buds while carefully avoiding sampling from the cupula area where the tissues of the parasite and host intertwine. Rafflesia species have a high bud mortality rate (50-90\%; Nais 2001 and references therein) and we therefore considered sampling from young buds as having a lower negative impact on the reproductive success of plants than sampling from mature buds that have escaped the causes of early mortality (e.g. nutrient limitation, predation by animals, infection by wasps; Nais 2001) and are likely to survive until the flowering stage. Voucher specimens (Appendix 1) are deposited at CAHUP, CANU, PNH, and SIU (acronyms follow Thiers 2017).

Development of Microsatellite Primers-Contigs from a previously published Illumina sequence library of $R$. lagascae obtained from a sample of this species from Bolos Point (see Molina et al. 2014 for assembly methodology; NCBI Sequence Read Archive SRX434531, Bioproject PRJNA235228; Fig. 1) were screened using MSATCOMMANDER 1.0.8beta (Faircloth 2008) for microsatellite loci of two or three nucleotides with a minimum of 15 repeats. This resulted in the identification of 1,254 microsatellite loci. The embedded Primer3 software (Rozen and Skaletsky 1999) subsequently designed M13-tagged universal primers for these using the following settings: melting temperatures $(\mathrm{Tm})$ of $58-60^{\circ} \mathrm{C}$, GC content of $40-60 \%$, and fragment sizes of $100-450 \mathrm{bp}$. This resulted in primers for 37 loci, which were screened for amplification success and specificity using DNA of four R. lagascae specimens. A total of 17 polymorphic loci (Table 1) were subsequently used for genotyping the additional DNA samples of $R$. lagascae and $R$. manillana available to us. A blastn search using the contig DNA sequences that contain these 17 loci did not reveal resemblance with available Vitaceae genomic data in GenBank. We therefore assume that none of these loci are present in the genome of $R$. lagascae as a result of horizontal gene transfer from their host plants.

DNA Extraction and Microsatellite Genotyping-Total genomic DNA for the microsatellite genotyping analyses was extracted using the Qiagen
DNeasy plant mini kit (Qiagen, Germantown, Maryland) following the manufacturer's protocol. Multiplex PCR analyses using up to four primer combinations per PCR sample were performed in a total volume of $4 \mu \mathrm{l}$ using the Qiagen Type-it microsatellite PCR kit. These samples contained $1 \mu$ l of genomic DNA (ca. $2-60$ ng per sample), $2 \mu l$ of $2 \times$ PCR master mix, $0.16 \mathrm{pmol}$ of M13-tagged primer, $0.64 \mathrm{pmol}$ of untagged primer, 2 pmol of M13 fluorescent-labeled primer (6FAM, NED, PET, or VIC; $5^{\prime}$ GGAAACAGCTATGACCAT- $3^{\prime}$ ) and nuclease-free water to volume. The PCR conditions were as follows: an initial denaturation of $5 \mathrm{~min}$ at $95^{\circ} \mathrm{C}$ followed by $30 \mathrm{sec}$ at $95^{\circ} \mathrm{C}, 90 \mathrm{sec}$ at $60^{\circ} \mathrm{C}, 30 \mathrm{sec}$ at $72^{\circ} \mathrm{C}$, during 28 cycles, and a final extension of $30 \mathrm{~min}$ at $60^{\circ} \mathrm{C}$. The PCR products were run on an ABI 3130xL Genetic Analyzer at the University of Canterbury. Geneious 6.1.7 (Biomatters Ltd, Auckland, New Zealand) was used to determine fragment lengths.

Data Analyses-We genotyped 143 DNA samples of the R. lagascae complex obtained from 80 host plants. Microsatellite data of 98 of these samples were included in our analyses. A total of 45 DNA samples were excluded, because these had identical genotypes to those of other flowers or buds obtained from the same host plant and might therefore represent the same Rafflesia individual.

Exact tests for deviations from Hardy-Weinberg equilibrium and linkage disequilibrium were performed with GENEPOP v. 4.2 (Raymond and Rousset 1995) as implemented in GenePop on the web (http:// genepop.curtin.edu.au/) and significance levels were adjusted for multiple tests using the B-Y method FDR at $p=0.05$ (Narum 2006). Only loci found to display significant linkage disequilibrium across all populations were considered to be linked. Micro-checker v. 2.2.3 (Van Oosterhout et al. 2004) was used to check for null alleles (95\% confidence interval; 1,000 repetitions). Only loci indicated to display null alleles across all populations were considered to be truly producing null alleles.

GenAlEx v. 6.5 (Peakall and Smouse 2012) was used to assess the genetic diversity of each population by calculating the percentage of polymorphic loci, allelic richness (mean number of alleles and number of effective alleles), observed $\left(\mathrm{H}_{\mathrm{o}}\right)$ and expected $\left(\mathrm{H}_{\mathrm{e}}\right)$ heterozygosity, unbiased heterozygosity $\left(\mathrm{uH}_{\mathrm{e}}\right)$, and the inbreeding coefficient. BOTTLENECK 1.2.0.2.

TABLE 1. Characteristics of microsatellite loci for Rafflesia lagascae and R. manillana. Annealing temperature was $60^{\circ} \mathrm{C}$ for all loci. Underlined nucleotides within primers indicate the M13 tag.

\begin{tabular}{|c|c|c|c|c|}
\hline Locus & Primer sequences $\left(5^{\prime}-3^{\prime}\right)$ & Repeat motif & Allele size range (bp) & GenBank accession no. \\
\hline \multirow[t]{2}{*}{ Man78 } & F: CCTTGTCACTGCCCATTTCC & AG & $186-232$ & KX212099 \\
\hline & R: GGAAACAGCTATGACCATCAGTTCATGCGGACCCATC & & & \\
\hline \multirow[t]{2}{*}{ Man80 } & F: $\overline{\text { TCAGGATTCGTGAGCCAAGG }}$ & $\mathrm{AC}$ & 269-297 & KX212101 \\
\hline & R: GGAAACAGCTATGACCATAACACAGGCCGAAGTTGATC & & & \\
\hline \multirow[t]{2}{*}{ Man109 } & F: ACGTAGTCATCCATTGAAAGGG & $\mathrm{AC}$ & $376-406$ & KX212086 \\
\hline & R: GGAAACAGCTATGACCATACTTGCCAGCCAGCTTC & & & \\
\hline \multirow[t]{2}{*}{ Man111 } & F: GTTGGATTCATCACGTTCATGC & $\mathrm{AC}$ & $398-449$ & KX212087 \\
\hline & R: GGAAACAGCTATGACCATCACCTTCGGCATTCATCCTG & & & \\
\hline \multirow[t]{2}{*}{ Man120 } & F: TGTTACTTTGTCTGCCCTTCAC & AG & 186-206 & KX212091 \\
\hline & R: GGAAACAGCTATGACCATGTGTATTCCAACGAGCAGG & & & \\
\hline Man142 & F: GGAAACAGCTATGACCATACCCAGGCAAGCGAAGTAC & AG & $328-346$ & KX212092 \\
\hline Man144 & $\begin{array}{l}\text { F: GGAAACAGCTATGACCATTTCCTCTTCAGCCAGTCGG } \\
\text { R: GTACTCATGAGGTTGTTGGCG }\end{array}$ & $\mathrm{AC}$ & 179-195 & KX212093 \\
\hline Man166 & $\begin{array}{l}\text { F: GGAAACAGCTATGACCATGCCCATACATATCCATACACC } \\
\text { R: CCCAAGCTCACACAAAGGAG }\end{array}$ & $\mathrm{AC}$ & $101-145$ & KX212094 \\
\hline Man171 & $\begin{array}{l}\text { F: GGAAACAGCTATGACCATGCCGCCTTCACCATTAATC } \\
\text { R: AGAAGCGAGGTGAAATGATCTC }\end{array}$ & AAT & $238-265$ & KX212095 \\
\hline Man273 & $\begin{array}{l}\text { F: GCGTGGTTCATTCATGGAGG } \\
\text { R: GGAAACAGCTATGACCATAACTTCAGGCCCTTCTCTCG }\end{array}$ & $\mathrm{AC}$ & $203-238$ & KX212096 \\
\hline Man553 & $\begin{array}{l}\text { F: GGAAACAGCTATGACCATCCACATGCACTCTACCCTC } \\
\text { R: TGAGAAAGACTTTGGGAGATGG }\end{array}$ & $\mathrm{AC}$ & $162-197$ & KX212097 \\
\hline Man714 & $\begin{array}{l}\text { F: GGAAACAGCTATGACCATGTGCGTGCATAACTAACCC } \\
\text { R: CATTAGGCTCTGCACACCTTG }\end{array}$ & AC & $220-288$ & KX212098 \\
\hline Man788 & $\begin{array}{l}\text { F: GGAAACAGCTATGACCATCCTTCACTTCCACACTACACC } \\
\text { R: AGAGATGGGTGGGAAAGGAAG }\end{array}$ & AG & $334-352$ & KX212100 \\
\hline Man866 & $\begin{array}{l}\text { F: ATCTACATGAGTCTGTGTGCC } \\
\text { R: GGAAACAGCTATGACCATACAGTTACACAGAGACACTTGG }\end{array}$ & $\mathrm{AC}$ & 147-171 & KX212102 \\
\hline Man1134 & $\begin{array}{l}\text { F: GGAAACAGCTATGACCATCCTAGACCTTGGTTTGGG } \\
\text { R: TTTAGCCTGGGTTTGGAGGG }\end{array}$ & $\mathrm{AC}$ & $439-464$ & KX212088 \\
\hline Man1169 & $\begin{array}{l}\text { F: CTTTGGTCGAGTAAGGCTAGTC } \\
\text { R: GGAAACAGCTATGACCATACCTCAACTTCAATGCGTGC }\end{array}$ & $\mathrm{AC}$ & $130-176$ & KX212089 \\
\hline Man1193 & $\begin{array}{l}\text { F: GGAAACAGCTATGACCATCCCTCTCCCACTATTTATCGAC } \\
\text { R: ACAAGCAAGGAAGATAGACGG }\end{array}$ & AG & $331-356$ & KX212090 \\
\hline
\end{tabular}


(Cornuet and Luikart 1997) was used to test for recent genetic bottlenecks in the six Rafflesia populations from which at least nine genetically unique samples were available. Wilcoxon sign-rank tests were used to determine if excesses in heterozygosity are statistically significant. Mode-shift tests in BOTTLENECK were employed to identify shifts in allele frequencies.

Genetic structure was studied by determining the number of private alleles for each population in GenAlEx. In addition, an analysis of molecular variance (AMOVA; $\mathrm{F}_{\text {st }} 999$ permutations) was carried out in GenAlEx with a data set from which samples from Mt. Banahaw and Mt. Mingan were excluded because only one Rafflesia sample was collected from each of these two areas. Bayesian model-based clustering analyses were performed with STRUCTURE v. 2.3.4 (Pritchard et al. 2000; Falush et al. 2003, 2007) using the admixture model and correlated allele frequencies. These analyses were run with $\mathrm{K}$ values from 1-20 and with 20 iterations for each $\mathrm{K}$ value. Each analysis was run for 200,000 generations of which the first 100,000 were discarded as burn-in. The STRUCTURE output was summarized using STRUCTURE HARVESTER (Earl and von Holdt 2012 ) to determine the value of $K$ that best explains the genetic structure in the data. For this, both the Evanno et al. (2005) method (K with the highest value of $\Delta \mathrm{K}$ ) and the method of Pritchard et al. (2000; $\mathrm{K}$ with the highest $\mathrm{Pr}$ $(\mathrm{X} \mid \mathrm{K})$ ) were used. CLUMPAK 1.1 (Kopelman et al. 2015) was used for the summation and graphical presentation of the STRUCTURE results. GenAlEx was subsequently used for a Principal Coordinate Analysis (PCoA) using a covariance matrix of co-dominant genotypic pairwise distances between individual samples with data standardization.

Mantel tests (999 replicates) were used in GenAlEx to test for a correlation between geographic distance and co-dominant genotypic distance between individuals. These tests were executed with non-transformed geographic distances as well as with a data set in which these distances were transformed using the natural logarithm.

\section{Results}

Patterns of genetic diversity and genetic structure in the $R$. lagascae complex were studied using microsatellite data from 17 loci. These loci yielded a total of 249 different alleles. The number of alleles per locus across all populations ranged from 5 to 33 (mean 14.59). After B-Y correction (Narum 2006), two of the 13 populations that were included in our study (Bolos Point and Mt. Irid) showed a significant $(p=0.05)$ deviation from Hardy-Weinberg proportions because of a deficit of heterozygotes (Table 2). Overall, however, the observed heterozygosity $\left(\mathrm{H}_{\mathrm{o}}=0.60\right)$ was only slightly higher or lower than estimates of the expected heterozygosity $\left(\mathrm{H}_{\mathrm{e}}=0.53\right.$, $\left.\mathrm{uH}_{\mathrm{e}}=0.64\right)$. None of the pairs of loci displayed significant linkage disequilibrium across all populations and none of the 17 loci showed evidence of producing null alleles across all populations.

For 32 of the 80 Tetrastigma host plants of the R. lagascae complex that were examined, more than one Rafflesia flower or flower bud was genotyped. Two different Rafflesia genotypes were obtained from 17 of these hosts (53\%), and three different parasite genotypes were recovered from one host plant. A total of 57 of the 93 (61\%) Rafflesia flowers for which sex could be determined were staminate. Staminate and pistillate flowers with identical genotypes were found on four host plants from the Basey, Bolos Point, Maria Aurora, and Mt. Malinao populations. Non-identical Rafflesia genotypes from the same host have a mean co-dominant genetic distance of $16.5(\mathrm{n}=18$; range 1-32). Rafflesia samples that were obtained from different hosts were all genetically different.

Populations at Bolos Point, Mt. Irid, and Salazar show the highest levels of genetic diversity as measured by the percentage of polymorphic loci, their allelic richness, and heterozygosity (Table 2). The inbreeding coefficient is low for the species complex as a whole $\left(\mathrm{F}_{\mathrm{IS}}=-0.14\right)$. It is highest for the R. manillana population (Basey; $\mathrm{F}_{\mathrm{IS}}=0.11$ ) and the Mt. Irid population of $R$. lagascae $\left(\mathrm{F}_{\mathrm{IS}}=0.12\right)$. Wilcoxon tests in

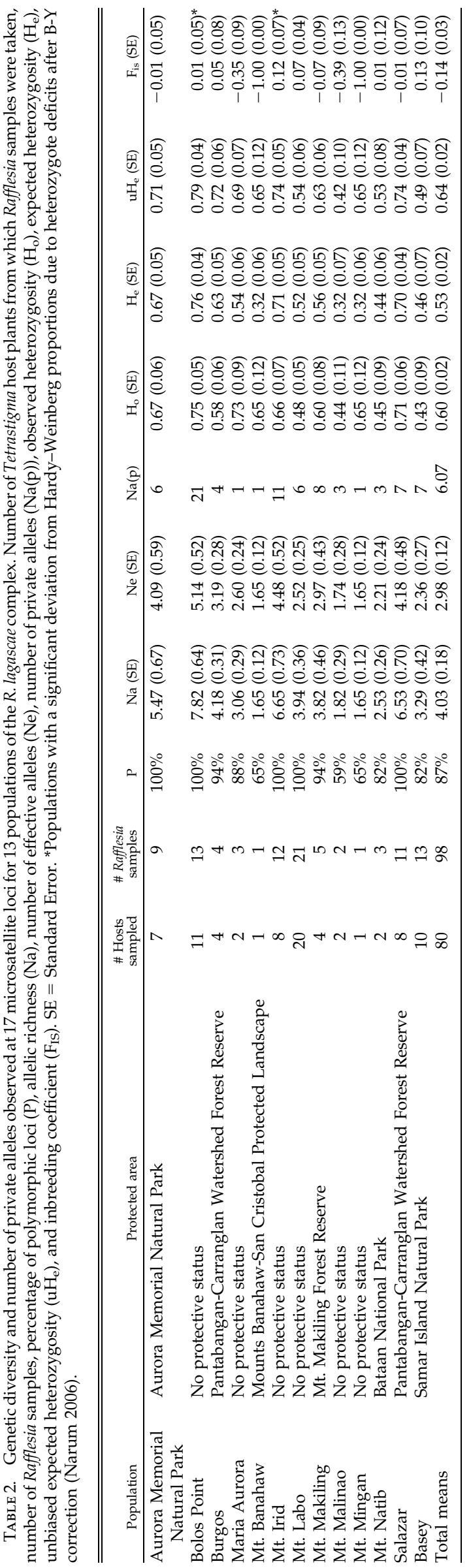


BOTTLENECK did not reveal a significant excess of heterozygotes in the six populations that were included in these tests when a Stepwise Mutation Model was assumed. However, significant heterozygosity excess was found for the Aurora Memorial Natural Park (AMNP) and Basey populations under the Infinite Alleles Model and the Two Phase Model. The Bolos Point, Mt. Irid, and Mt. Labo populations only displayed significant heterozygosity excess under an Infinite Alleles Model. The AMNP population shows evidence of a shift in allelic frequencies.

All 13 populations of the R. lagascae complex have at least one private allele (Table 2). The Bolos Point and Mt. Irid populations have the most private alleles (21 and 11, respectively). Overall genetic differentiation within the $R$. lagascae complex is significant $\left(\mathrm{F}_{\mathrm{ST}}^{\prime}=0.651, p<0.001\right)$. A total of $22 \%$ of the genetic variation was found among populations and $9 \%$ among individuals. All pairwise $\mathrm{F}_{\mathrm{ST}}$ values are statistically significant at $p=0.05$ after B-Y correction (Narum 2006), except for the population pairs Burgos-Salazar and Burgos-Mt. Irid (Table 3). Using the Pritchard et al. (2000) and Evanno et al. (2005) methods, the results of the STRUCTURE analysis identified three primary genetic clusters $(K=3)$. One of these clusters is solely composed of specimens of the Basey population ( $R$. manillana), the second cluster exclusively contains $R$. lagascae specimens from Mt. Labo, and all specimens of the remaining $11 R$. lagascae populations form the third cluster (Fig. 3). The admixture proportions ( $q$ values) for individual specimens indicate very little admixture between the three clusters. The same genetic clusters were also recovered in a PCoA of pairwise genetic distances (Fig. 4).

To study patterns of genetic structure within R. lagascae s. s., STRUCTURE analyses were also performed with a data set that contains only populations of this group. For this data set, the Evanno et al. (2005) method favored $K=2$, whereas the Pritchard et al. (2000) method preferred $K=8$. The STRUCTURE plots of $\mathrm{K}=2$ (Fig. 5A) show that the Bolos Point population in the northern part of Luzon (Fig. 1) is placed in the same genetic cluster as populations from the southern part of mainland Luzon (Mt. Banahaw, Mt. Makiling, Mt. Natib), and the Bicol peninsula (Mt. Malinao). The remaining populations of $R$. lagascae s. s. are found in central Luzon (AMNP, Burgos, Maria Aurora, Mt. Irid, Mt. Mingan, Salazar) and show a pattern of admixture between both genetic clusters (Fig. 5A). The $\mathrm{K}=8$ STRUCTURE plots (Fig. 5B; only the major clustering pattern presented) show that some nearby populations have similar genetic profiles (AMNP, Maria Aurora, and Mt. Mingan; Burgos and Salazar), that some genetic clusters are predominantly found in individual populations (e.g. Mt. Makiling, Mt. Natib, Mt. Irid), and that some populations are mostly composed of specimens with high $q$ values for a single genetic cluster (e.g. AMNP, Mt. Makiling, Mt. Malinao). Overall genetic differentiation within the $R$. lagascae s. s. cluster is significant $\left(\mathrm{F}^{\prime}{ }_{\mathrm{ST}}=0.420, p<0.001\right)$. A total of $12 \%$ of the genetic variation was found among populations and $9 \%$ among individuals. Within $R$. lagascae s. s., Mantel tests did not reveal a statistically significant positive correlation at $p=0.05$ between geographic and genetic distances.

\section{DiscUSSION}

Because of the size of their flowers, which are among the largest in the world (Nais 2001), and their intriguing parasitic life style, Rafflesia species speak to the imagination of biologists and the general public alike. This fascination is further heightened by the fact that many Rafflesia species are very rare. For example, R. schadenbergiana Göpp. ex Hieron. (Hieronymus 1885) is currently known from only two living host plants (Barcelona et al. 2008; Pelser et al. 2016). As such, Rafflesia are flagships of plant conservation: the giant pandas of the plant world (Josephson 2000). Yet, to the best of our knowledge, conservation genetic studies have not previously been attempted and, consequently, nothing was thus far known about the patterns of genetic diversity and structure of Rafflesia species. This is not because of a lack of interest by biologists, but rather because of difficulties typically associated with studying rare species with small population sizes. Even R. lagascae, the most common and widespread species of Rafflesia in the Philippines, is only known from 15 areas and few Tetrastigma host plants. For that reason, it is difficult to attain sample sizes that provide enough statistical power to conclusively answer population genetic questions. Although we sampled 13 of the 16 known populations of the R. lagascae complex, and went through great efforts to locate as many host plants as possible, many Rafflesia populations appear to consist of only a single or very few host plants that produce only a few flowers and, consequently, yielded few samples for our molecular genetic analyses. For example, from two populations (Mt. Banahaw and Mt. Mingan) only a single sample could be obtained (Table 2). This means that, despite extensive sampling, our results should be interpreted with care and that our conclusions are tentative. However, although the absolute number of Rafflesia specimens that we sampled was small, the percentage of individuals sampled in each population is very high. Therefore, despite of low sample numbers in some populations, our research resulted in very accurate estimates of population allele frequencies.

TABLE 3. Pairwise $\mathrm{F}_{\mathrm{st}}$ values between populations of the R. lagascae complex. *Non-significant pairwise comparisons after B-Y correction (Narum 2006).

\begin{tabular}{|c|c|c|c|c|c|c|c|c|c|c|c|}
\hline & & $\begin{array}{l}\text { Bolos } \\
\text { Point }\end{array}$ & $\begin{array}{l}\text { Aurora Memorial } \\
\text { Natural Park }\end{array}$ & $\begin{array}{c}\text { Maria } \\
\text { Aurora }\end{array}$ & Salazar & Burgos & Mt. Irid & Mt. Natib & $\begin{array}{c}\text { Mt. } \\
\text { Makiling }\end{array}$ & $\begin{array}{c}\text { Mt. } \\
\text { Malinao }\end{array}$ & $\begin{array}{l}\text { Mt. } \\
\text { Labo }\end{array}$ \\
\hline R. lagascae & Bolos Point & & & & & & & & & & \\
\hline R. lagascae & Aurora Memorial Natural Park & 0.088 & & & & & & & & & \\
\hline R. lagascae & Maria Aurora & 0.100 & 0.053 & & & & & & & & \\
\hline R. lagascae & Salazar & 0.077 & 0.074 & 0.120 & & & & & & & \\
\hline R. lagascae & Burgos & 0.099 & 0.087 & 0.127 & $0.004^{*}$ & & & & & & \\
\hline R. lagascae & Mt. Irid & 0.066 & 0.066 & 0.100 & 0.042 & $0.037^{*}$ & & & & & \\
\hline R. lagascae & Mt. Natib & 0.147 & 0.209 & 0.263 & 0.184 & 0.192 & 0.169 & & & & \\
\hline R. lagascae & Mt. Makiling & 0.120 & 0.186 & 0.227 & 0.168 & 0.182 & 0.131 & 0.211 & & & \\
\hline R. lagascae & Mt. Malinao & 0.254 & 0.309 & 0.393 & 0.209 & 0.282 & 0.239 & 0.385 & 0.387 & & \\
\hline R. lagascae & Mt. Labo & 0.232 & 0.318 & 0.373 & 0.283 & 0.343 & 0.275 & 0.386 & 0.304 & 0.413 & \\
\hline R. manillana & Basey & 0.245 & 0.268 & 0.338 & 0.217 & 0.265 & 0.214 & 0.375 & 0.385 & 0.381 & 0.412 \\
\hline
\end{tabular}




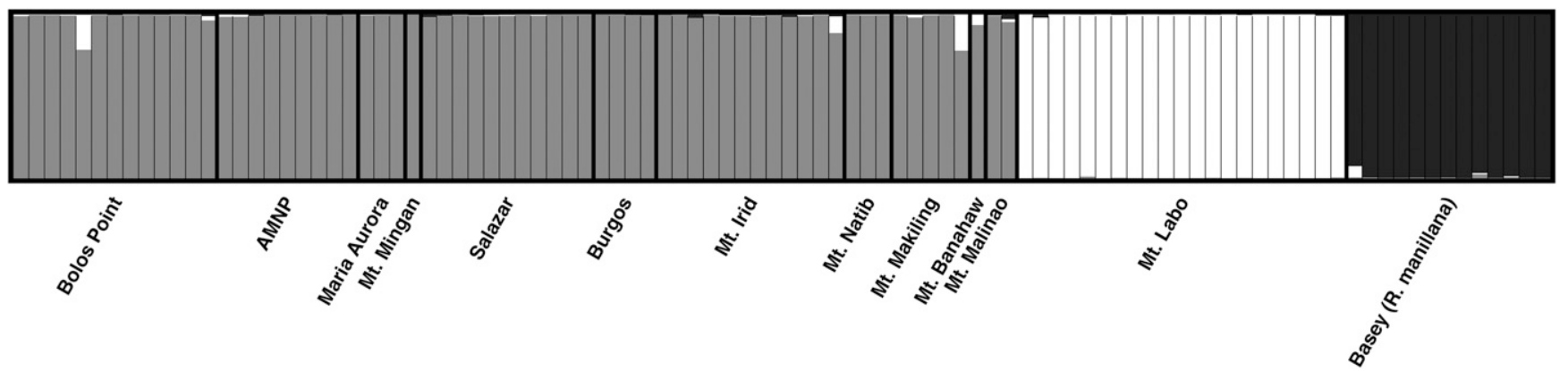

FIG. 3. $\mathrm{K}=3$ STRUCTURE results for the R. lagascae complex. Each bar represents an individual plant and bar colors indicate the proportion of membership to each genetic cluster ( $q$ values). Individuals are grouped by population. ANMP = Aurora Memorial Natural Park.

Breeding System and Co-infection of Hosts-Genetically identical Rafflesia samples were exclusively obtained from the same host plant and Rafflesia samples from the same host plant that are not genetically identical have a mean co-dominant genetic distance of 16.5. This indicates that our microsatellite data set of 17 loci potentially provides enough resolution at the level of individuals to determine if plants of the $R$. lagascae complex are dioecious or monoecious. Under this assumption, our data indicate that this complex is monoecious, because genetically identical staminate and pistillate flowers were found on the same host plants. Previously, however, Rafflesia was hypothesized to be dioecious (e.g. Olah 1960; Beaman et al. 1988; Renner and Feil 1993; Bellot and Renner 2013; Wicaksono et al. 2016; but see Nais 2001 for more cautious statements). This reproductive strategy was considered more likely because Rafflesia species are rare and populations are far apart. Dioecy was therefore regarded as a likely adaptation to avoid inbreeding depression (Beaman et al. 1988). Two species, $R$. baletei Barcelona and Cajano (Barcelona et al. 2006) and $R$. verrucosa Balete, Pelser, Nickrent \& Barcelona. (2010), however, have both stamens and a developed ovary on the same flower, although it is unknown if these are also functionally bisexual. In addition, non-functional stamens have been reported for some female flowers of $R$. consueloae Galindon, Ong and Fernando (2016). If plants of the Rafflesia lagascae complex and other Rafflesia species are monoecious, it remains to be determined if they are self-compatible and geitonogamous or exclusively outcrossing. A geitonogamous breeding system might benefit small Rafflesia populations, because it increases the number of available mates, however, it carries with it the

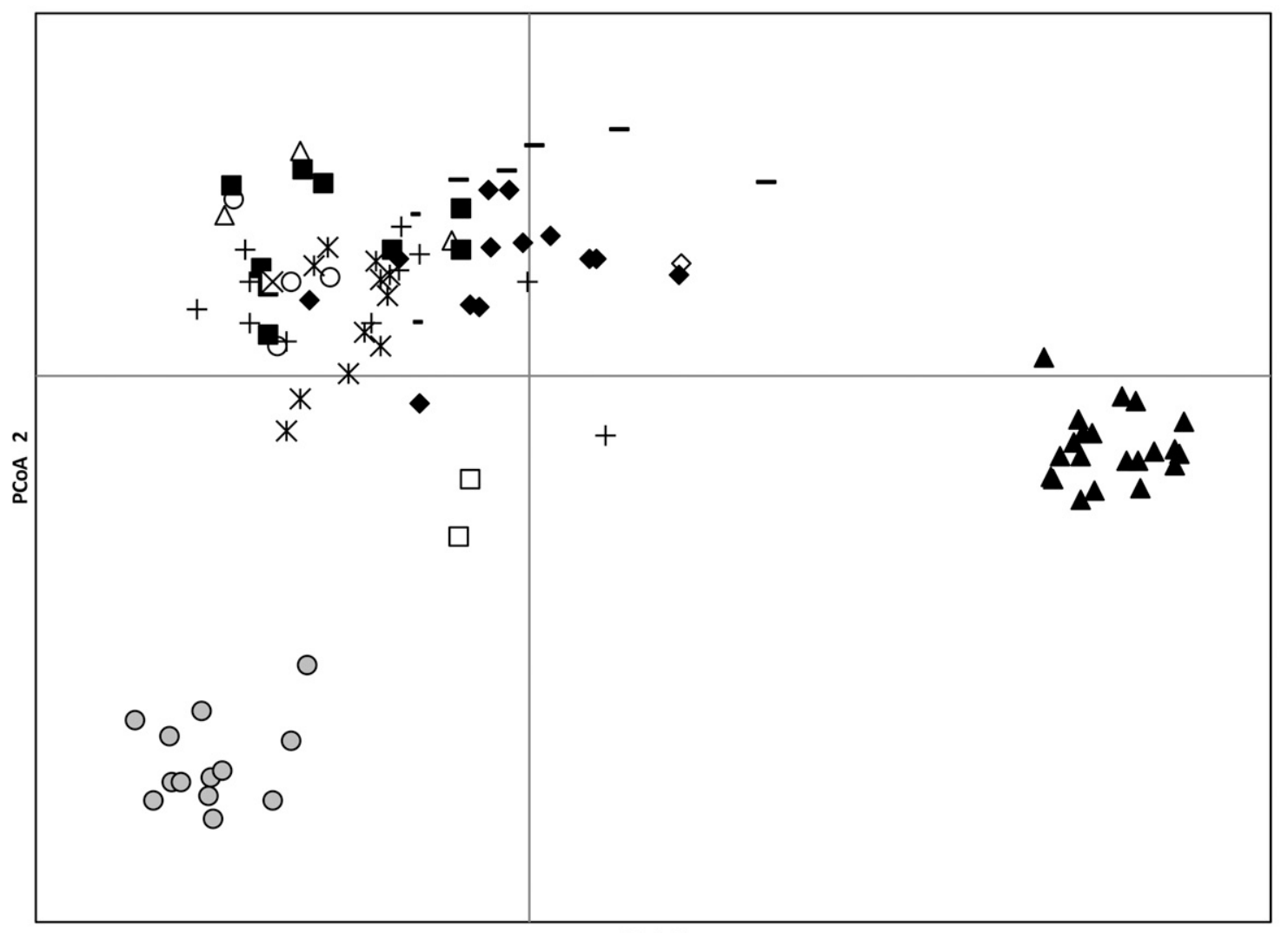

Bolos Point
- AMNP

$\triangle$ Maria Aurora

XMt. Mingan

*Salazar

O Burgos

+Mt. Irid

- Mt. Natib

- Mt. Makiling

$\diamond \mathrm{Mt}$. Banahaw

$\square$ Mt. Malinao

A Mt. Labo

O Basey (R. manillana)

PCOA 1

FIG. 4. The PCoA ordination of the R. lagascae complex using a covariance matrix of co-dominant genotypic pairwise distances between individual samples with data standardization. The first and second PCoA axes explain $15.5 \%$ and $8.6 \%$ of the variation respectively. ANMP $=$ Aurora Memorial Natural Park. 
A

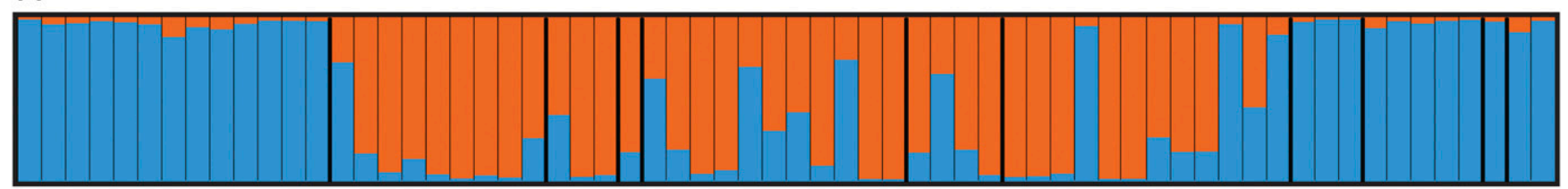

B

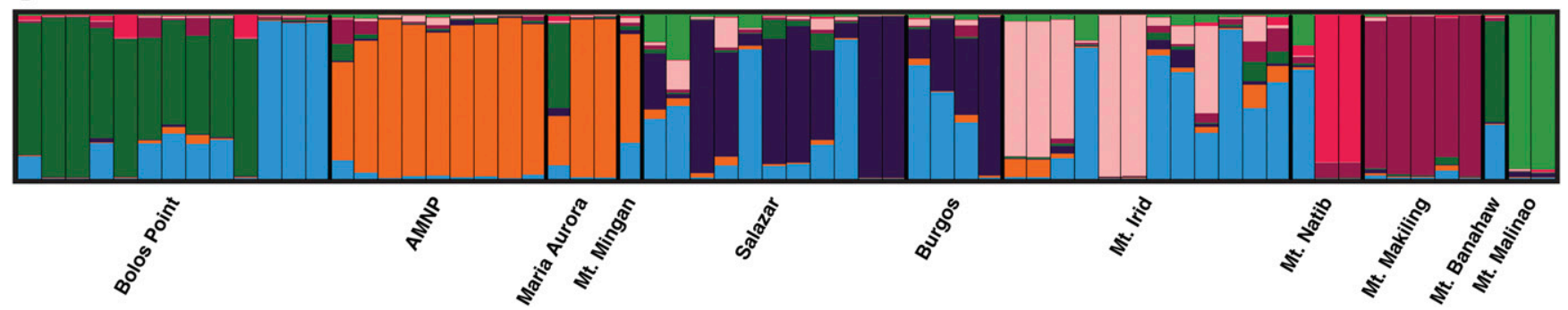

FIG. 5. STRUCTURE results for R. lagascae s. s. Each bar represents an individual plant and bar colors indicate the proportion of membership to each genetic cluster ( $q$ values). Individuals are grouped by population. A. $\mathrm{K}=2$. B. $\mathrm{K}=8$. Only the major clustering pattern is shown. ANMP $=\mathrm{Aurora}$ Memorial Natural Park.

potentially negative consequences of inbreeding (Byers and Meagher 1992; Ellstrand and Elam 1993). Some studies have suggested that dioecy is overrepresented in parasitic plants (Renner and Ricklefs 1995; Bellot and Renner 2013), but this hypothesis rests in part on the assumption that the presence of pistillate and staminate flowers of endophytic parasites on the same host belong to different parasite individuals (Bellot and Renner 2013). If endophytic parasites with unisexual flowers such as those in Apodanthaceae and Rafflesiaceae are indeed monoecious, then the incidence of dioecy among all parasites has been overestimated.

For Tetrastigma host plants from which more than one Rafflesia sample was taken, genetically different Rafflesia flowers were recovered from about half. This suggests that Tetrastigma host plants are regularly home to multiple genetically distinct Rafflesia individuals. Consequently, even populations composed of a single host plant can maintain genetic diversity. Potentially, the monoecious breeding system and co-infection of host plants enable the R. lagascae complex to maintain viable populations in areas with low host densities.

Genetic Diversity-The numbers of samples taken from each Rafflesia population can be considered as rough estimates of relative population sizes, because we sampled Rafflesia from nearly all encountered infected host plants that produced flower buds or flowers during our field work. Although smaller populations of the $R$. lagascae complex typically display less genetic diversity than larger populations, as measured by the percentage of polymorphic loci, allelic richness, and heterozygosity estimates, they are not genetically depauperate and do not show evidence of marked inbreeding (Table 2), as might be expected for small and isolated populations (Ellstrand and Elam 1993; although see Binks et al. 2015 and references therein). Overall, heterozygosity estimates are similar to those of other perennial plant species (Nybom 2004). Six populations for which at least nine genetically unique samples were available were included in analyses to test for indications of recent genetic bottlenecks. Although we did not find evidence for a genetic bottleneck in the Salazar population, there are indications that the other populations (AMNP, Basey, Bolos Point, Mt. Irid, Mt. Labo) might have experienced a genetic bottleneck in the recent past. However, if they indeed went through a genetic bottleneck, it is at present not known what caused this, because all five populations are located in areas with relatively intact forests.

Genetic Structure-The results of the genetic structure analyses indicate low genetic connectivity between most populations of the $R$. lagascae complex. All populations have one or more private alleles (Table 2), most pairwise $\mathrm{F}_{\mathrm{ST}}$ values and the overall $\mathrm{F}_{\text {ST }}$ value are statistically significant (Table 3), and a substantial proportion of the genetic variation in the complex is found among populations. The results of the STRUCTURE and PCOA analyses show that there are three distinct genetic groups that align with $R$. manillana, the Mt. Labo $R$. lagascae population, and the 11 remaining populations of $R$. lagascae (Figs. 3, 4). These patterns suggest that these three groups are genetically isolated from each other.

The distinctiveness of $R$. manillana as indicated by the microsatellite data used in this study is supported by morphological differences between this taxon and $R$. lagascae (Madulid and Agoo 2008; Madulid et al. 2008; Pelser et al. 2013; Fig. 2). Except for R. speciosa Barcelona and Fernando (2002), which is found on the island of Panay and the adjacent northern part of Negros Island (Barcelona et al. 2009), all Philippine Rafflesia species are endemic to individual islands in the archipelago. Rafflesia manillana is endemic to Samar Island whereas R. lagascae is only known from Luzon Island and their genetic and morphological differences therefore support the hypothesis that the sea straits that separate the Philippine islands form significant barriers to gene flow between Rafflesia populations. The genetic isolation of $R$. manillana might be a contributing factor to its lower genetic diversity relative to most other populations from which a similar number of samples was obtained (Table 2).

Also the Mt. Labo R. lagascae population is genetically isolated from other populations of the complex and likewise shows relatively low genetic diversity (Table 2). In contrast with R. manillana, however, the Mt. Labo population does not appear to be morphologically different from the other $R$. lagascae populations (Fig. 2). Its floral characters (e.g. size, coloration, ornamentation of the diaphragm and perigone lobes) seem to fall within the range of variation observed in $R$. lagascae s. s., but detailed morphometric studies are needed to determine if the Mt. Labo population is indeed morphologically indistinct from R. lagascae s. s. Pelser et al. (2016) 
identified Tetrastigma loheri Gagnepain (1910) as the host species of Mt. Labo Rafflesia plants. This species is the most common host of the $R$. lagascae complex (Pelser et al. 2016) and differences in host preference can therefore not explain the genetic distinctiveness of the Mt. Labo population.

Mt. Labo is located on Bicol Peninsula, which is currently connected to mainland Luzon by a relatively narrow land bridge, and at the southeastern end of the distribution area of R. lagascae (Fig. 1). According to Hall (1998, 2002), the Bicol Peninsula was part of a cluster of islands that included Samar and eastern parts of the current Visayas and Mindanao and that has progressively moved towards mainland Luzon over the last 45 my. The Bicol Peninsula connected to southeastern Luzon only ca. 6 mya (Hall 2002). The genetic isolation of the Mt. Labo population can therefore potentially be explained by the geographical isolation of the Bicol Peninsula prior to 6 mya. Molecular dating studies by Bendiksby et al. (2010) suggest that Rafflesia was present in the Philippines as early as 5.2-9.3 mya. Thus, it is indeed possible that the dynamic geological history of the Philippines shaped the patterns of genetic structure of $R$. lagascae. The Mt. Malinao population, however, is also located on the Bicol Peninsula (Fig. 1), yet genetically more similar to populations from mainland Luzon than to the Mt. Labo population (Fig. 3). If the previously mentioned geographic hypothesis is correct, then long-distance dispersal of Rafflesia lagascae s. s. between mainland Luzon to Mt. Malinao could explain the observed genetic patterns. Zoochory has been proposed as the dispersal method of Rafflesia seeds (Teijsmann 1856; Justesen 1922; Kuijt 1969; Emmons et al. 1991; Nais 2001; Bänziger 2004). Although various animals have been considered as dispersal agents, observations by Pelser et al. (2013) suggest seed dispersal by ants. Myrmecochory is potentially plesiomorphic in Rafflesiaceae, because it is also common in Peraceae (Bond and Slingsby 1983; Lengyel et al. 2009, 2010), which form the sister group of the clade composed by Euphorbiaceae and Rafflesiaceae (Davis et al. 2007; Endress et al. 2013). If Rafflesia is indeed myrmecochorous, long-distance dispersal is presumably very rare, and this might explain the high island-endemicity of Rafflesia in the Philippines. However, other observations and experiments suggest that mammalian frugivores might play a role in endozoochorous seed dispersal (Emmons et al. 1991; Bänziger 2004) and this mode of dispersal might be able to transport Rafflesia seeds more frequently over greater distances. Alternatively, the Mt. Malinao area might be a fragment of mainland Luzon whose position has been scrambled by tectonic movement of the Bicol fragment. Although we are not aware of geological evidence that supports this hypothesis, this part of the Philippines clearly has a very complex and dynamic geological history that is presently only poorly known (Hall 2002).

Patterns of genetic structure within R. lagascae s. s. are less pronounced than those among $R$. lagascae s. s., Mt. Labo $R$. lagascae, and $R$. manillana, but still indicate low genetic connectivity among most populations (Table 2; Figs. 4, 5). However, particularly some populations in central Luzon (i.e. Burgos, Mt. Irid, Salazar) show admixture between different genetic clusters (Fig. 5) and might therefore have experienced higher levels of recent gene flow than some of the other populations (e.g. Mt. Makiling and Mt. Malinao). Although evidence for isolation by distance in the R. lagascae s. s. cluster is not statistically significant, pairwise $F_{S T}$ values (Table 3) and the results of Bayesian cluster analyses in STRUCTURE (Fig. 5) suggest stronger genetic connectivity within two groups of nearby populations in central Luzon (i.e. among the AMNP, Maria Aurora, and Mt. Mingan populations and between Burgos and Salazar) than among other populations. This indicates that nearby populations are perhaps less likely to become genetically isolated than those that are further away or that genetic connectivity between populations in central Luzon is higher than in other parts of the distribution area of $R$. lagascae.

Taxonomic Delimitation of the R. lagascae Complex-The results of our genetic structure analyses inform the taxonomic delimitation of the $R$. lagascae complex. In addition to confirming that $R$. manillana is not only morphologically different from $R$. lagascae (Fig. 2), but also genetically distinct, we also demonstrate that a genetically different but morphologically cryptic population of $R$. lagascae exists on Mt. Labo. If a species concept is applied in which genetic distinctiveness or the absence of interbreeding is considered evidence for recognizing groups of individuals as different species (Coyne and Orr 2004), then the Mt. Labo population should be described as a distinct species. We refrain here from formally naming this species, awaiting the completion of detailed morphological studies in search of characters in which the Mt. Labo plants are different from those of $R$. lagascae s. s.

Conservation Implications-The $R$. lagascae complex is known from relatively few and disjunct populations, some of which are only composed of a few host plants. Despite this, our results do not provide evidence of pronounced inbreeding and populations show moderate levels of genetic diversity. This potentially means that the disjunct distribution of the $R$. lagascae complex and the small sizes of some of its populations are a result of natural differences in host presence and abundance among areas and that the $R$. lagascae complex has adapted to this. In other words, the R. lagascae complex is possibly naturally rare. It is extremely likely, however, that the number of populations of the R. lagascae complex has decreased over the past century and that the geographic distances between them have increased as a result of widespread habitat destruction and degradation in the Philippines (Mittermeier et al. 1998; Ong et al. 2002). Especially in the southern part of its distribution in Luzon, the natural forest ecosystems in which $R$. lagascae is found are confined to small areas separated by vast areas in which forests have been converted to farmland. This has undoubtedly resulted in decreased genetic connectivity between the remaining populations.

Our results show substantial differences in allelic composition and frequencies between populations of the $R$. lagascae complex (Table 2). This means that considerable genetic diversity might be lost if any of its populations would go extinct (Schmidt and Jensen 2000). Small or isolated populations outside of protected areas are most at risk of extinction. These include the populations from Maria Aurora, Mt. Malinao, and Mt. Mingan (Table 2). However, also the larger populations outside of protected areas (Bolos Point, Mt. Irid, and Mt. Labo) are of conservation concern, because they harbor the highest levels of genetic diversity and need to be protected from habitat destruction and degradation to remain centers of genetic diversity.

Because of their pronounced genetic differences and the lack of gene flow between them, $R$. lagascae s. s., Mt. Labo $R$. lagascae, and $R$. manillana should be managed as distinct conservation entities. Mt. Labo R. lagascae and R. manillana are each only known from a single population, which shows lower 
genetic diversity than similar sized populations of $R$. lagascae s. s. (Table 2). Both taxa therefore have a higher risk of losing genetic diversity and of becoming extinct than R. lagascae s. s. The habitat of $R$. manillana is protected as part of the Samar Island Natural Park and is relatively intact, but the Mt. Labo area does not enjoy formal protection. The Mt. Labo Rafflesia is therefore particularly prone to experiencing a reduction in the size of its single population and should thus be managed as a critically endangered species (IUCN 2012).

If Rafflesia lagascae s. s. and the Mt. Labo Rafflesia are indeed morphologically cryptic species, then this poses the question of whether additional cryptic species have been overlooked in Rafflesia. If so, this could mean that Rafflesia species of conservation concern have remained undetected and that specieslevel biodiversity of Rafflesia has been underestimated (e.g. Schönrogge et al. 2002; Bickford et al. 2007; Shepherd et al. 2015). Future studies into species delimitation using genetic tools are therefore needed to be able to better inform Rafflesia conservation management.

AcKnowledgments. This publication is dedicated to Danilo S. Balete (1960-2017), mammologist and discoverer of three new species of Philippine Rafflesia. This project was funded by the Marsden Fund Council from Government funding administered by the Royal Society of New Zealand and by the Linnean Society, Percy Sladen Memorial Fund, and the National Geographic Foundation. We would like to thank the three anonymous reviewers of this manuscript for their valuable comments. We are grateful to the National Museum of the Philippines, the Department of Environment and Natural Resources (DENR) and in particular T. M. S. Lim, Director of the Biodiversity Management Bureau (BMB) and staff of the DENR regional and local offices for facilitating the issuance of collecting, transport, and export permits. Prior Informed Consents were issued by the Protected Areas and Management Boards (PAMB) of Aurora Memorial National Park, Bataan Natural Park (Mt. Natib), Pantabangan-Carranglan Watershed Reserve, Mt. Banahaw-Mt. San Cristobal Protected Area, Samar Island Natural Park, the Mayors of Buhi, Camarines Sur; Gattaran and Lal-o, Cagayan; Gabaldon, Nueva Ecija; Labo and San Lorenzo Ruiz, Camarines Norte; Rodriguez, Rizal, and the Makiling Center for Mountain Ecosystems. We would also like to thank our NGO partners: Cagayan Valley Partners in People Development and the Philippine Native Plants Conservation Society, Inc. For sharing information on distributional ranges and fieldwork assistance, we thank J. Aliposa, D. S. Baletet, M. O Cajanot, J. R. Callado, L. L. Cot, V. Dacumos, A. Diesmos, N. B. Gapas, J. Sarmiento, and D. Tandang. Numerous field guides/assistants and staff of DENR and LGU deserve our sincerest gratitude for without their help, fieldwork would have not been possible. Finally, M. L. Hale and T. E. Steeves provided helpful feedback on the results of the population genetic analyses and M. Walters helped with preparing figures for this publication.

\section{Literature Cited}

Balete, D. S., P. B. Pelser, D. L. Nickrent, and J. F. Barcelona. 2010. Rafflesia verrucosa (Rafflesiaceae), a new species of small-flowered Rafflesia from eastern Mindanao, Philippines. Phytotaxa 10: 49-57.

Bänziger, H. 2004. Studies on hitherto unknown fruits and seeds of some Rafflesiaceae, and a method to manually pollinate their flowers for research and conservation. Linzer Biologische Beiträge 36: 1175-1198.

Barcelona, J. F. and E. S. Fernando. 2002. A new species of Rafflesia (Rafflesiaceae) from Panay Island, Philippines. Kew Bulletin 57: 647-651.

Barcelona, J. F., M. O. Cajano, and A. S. Hadsall. 2006. Rafflesia baletei, another new Rafflesia (Rafflesiaceae) from the Philippines. Kew Bulletin 61: 231-237.

Barcelona, J. F., P. B. Pelser, A. M. Tagtag, R. G. Dahonog, and A. P. Lilangan. 2008. The rediscovery of Rafflesia schadenbergiana (Rafflesiaceae). Flora Malesiana Bulletin 14: 162-165.

Barcelona, J. F., P. B. Pelser, D. S. Balete, and L. L. Co. 2009. Taxonomy, ecology, and conservation status of Philippine Rafflesia. Blumea 54: 77-93.

Barcelona, J. F., M. M. E. Manting, R. B. Arbolonio, R. B. Caballero, and P. B. Pelser. 2014. Rafflesia mixta (Rafflesiaceae), a new species from Surigao del Norte, Mindanao, Philippines. Phytotaxa 174: 272-278.
Barkman, T. J., S. H. Lim, K. Mat Salleh, and J. Nais. 2004. Mitochondrial DNA sequences reveal the photosynthetic relatives of Rafflesia, the world's largest flower. Proceedings of the National Academy of Sciences USA 101: 787-792.

Barkman, T. J., M. Bendiksby, S.-H. Lim, K. M. Salleh, J. Nais, D. Madulid, and T. Schumacher. 2008. Accelerated rates of floral evolution at the upper size limit for flowers. Current Biology 18: 1508-1513.

Beaman, R. S., P. Decker, and J. Beaman. 1988. Pollination of Rafflesia (Rafflesiaceae). American Journal of Botany 75: 1148-1162.

Bellot, S. and S. S. Renner. 2013. Pollination and mating systems of Apodanthaceae and the distribution of reproductive traits in parasitic angiosperms. American Journal of Botany 100: 1083-1094.

Bendiksby, M., T. Schumacher, G. Gussarova, J. Nais, K. Mat-Salleh, N. Sofiyanti, D. Madulid, S. A. Smith, and T. Barkman. 2010. Elucidating the evolutionary history of the Southeast Asian, holoparasitic, giant-flowered Rafflesiaceae: Pliocene vicariance, morphological convergence and character displacement. Molecular Phylogenetics and Evolution 57: 620-633.

Besana, G. M. and M. Ando. 2005. The central Philippine Fault Zone: Location of great earthquakes, slow events, and creep activity. Earth, Planets, and Space 57: 987-994.

Bickford, D., D. J. Lohman, N. S. Sodhi, P. K. L. Ng, R. Meier, K. Winker, K. K. Ingram, and I. Das. 2007. Cryptic species as a window on diversity and conservation. Trends in Ecology E Evolution 22: 148-155.

Binks, R. M., M. A. Millar, and M. Byrne. 2015. Not all rare species are the same: Contrasting patterns of genetic diversity and population structure in two narrow-range endemic sedges. Biological Journal of the Linnean Society. Linnean Society of London 114: 873-886.

Blanco, F. M. 1845. Flora de Filipinas. Ed. 2. M. Manila: Sanchez.

Bond, W. J. and P. Slingsby. 1983. Seed dispersal by ants in shrublands of the Cape Province and its evolutionary implications. South African Journal of Science 79: 231-233.

Byers, D. L. and T. R. Meagher. 1992. Mate availability in small populations of plant species with homomorphic sporophytic self-incompatibility. Heredity 68: 353-359.

Cornuet, J. M. and G. Luikart. 1997. Description and power analysis of two tests for detecting recent population bottlenecks from allele frequency data. Genetics 144: 2001-2014.

Costea, M. and S. Stefanović. 2009. Cuscuta jepsonii (Convolvulaceae): An invasive weed or an extinct endemic?. American Journal of Botany 96: 1744-1750

Coyne, J. A. and H. A. Orr. 2004. Speciation: Reality and concepts. Pp. 9-25 in Speciation, eds. J. A. Coyne and H. A. Orr. Sunderland, Massachussetts: Sinauer Associates, Inc.

Davis, C. C. and K. J. Wurdack. 2004. Host-to-parasite gene transfer in flowering plants: Phylogenetic evidence from Malpighiales. Science 305: 676-678.

Davis, C. C., M. Latvis, D. L. Nickrent, K. J. Wurdack, and D. A. Baum. 2007. Floral gigantism in Rafflesiaceae. Science 315: 1812.

de Lange, P. J. 2003. Pittosporum serpentinum (de Lange) de Lange (Pittosporaceae), a new species combination for an ultramafic endemic from North Cape, New Zealand. New Zealand Journal of Botany 41: 725-726.

Earl, D. A. and B. M. von Holdt. 2012. STRUCTURE HARVESTER: A website and program for visualizing STRUCTURE output and implementing the Evanno method. Conservation Genetics Resources 4: 359-361.

Ellstrand, N. C. and D. R. Elam. 1993. Population genetic consequences of small population size: Implications for plant conservation. Annual Review of Ecology and Systematics 24: 217-242.

Emmons, L. H., J. Nais, and A. Briun. 1991. The fruit and consumers of Rafflesia keithii (Rafflesiaceae). Biotropica 23: 197-199.

Endress, P. K., C. C. Davis, and M. L. Matthews. 2013. Advances in the floral structural characterization of the major subclades of Malpighiales, one of the largest orders of flowering plants. Annals of Botany 111: 969-985.

Evanno, G., S. Regnaut, and J. Goudet. 2005. Detecting the number of clusters of individuals using the software structure: a simulation study. Molecular Ecology 14: 2611-2620.

Faircloth, B. C. 2008. Msatcommander: Detection of microsatellite repeat arrays and automated, locus-specific primer design. Molecular Ecology Resources 8: 92-94.

Falush, D., M. Stephens, and J. K. Pritchard. 2003. Inference of population structure: Extensions to linked loci and correlated allele frequencies. Genetics 164: 1567-1587. 
Falush, D., M. Stephens, and J. K. Pritchard. 2007. Inference of population structure using multilocus genotype data: Dominant markers and null alleles. Molecular Ecology Notes 7: 574-578.

Gagnepain, F. 1910. Tetrastigma (Ampélidacées) nouveaux ou peu connus. Notululae Systematicae 1: 261-271.

Galindon, J. M. M., P. S. Ong, and E. S. Fernando. 2016. Rafflesia consueloae (Rafflesiaceae), the smallest among giants: A new species from Luzon Island, Philippines. PhytoKeys 16: 37-46.

Hall, R. 1998. The plate tectonics of Cenozoic SE Asia and the distribution of land and sea. Pp. 99-131 in Biogeography and Geological Evolution of SE Asia, eds. R. Hall and J. D. Holloway. Leiden: Backhuys Publishers.

Hall, R. 2002. Cenozoic geological and plate tectonic evolution of SE Asia and the SW Pacific: Computer-based reconstructions, model and animations. Journal of Asian Earth Sciences 20: 353-431.

Hidayati, S. N. and J. L. Walck. 2016. A review of the biology of Rafflesia: What do we know and what's next? Buletin Kebun Raya 19: 67-78.

Hieronymus, G. 1885. Ueber eine neue, von Dr. A. Schadenberg und O. Koch auf Süd-Mindanao entdeckte Art der Gattung Rafflesia. Gartenflora 34: 3-7.

IUCN. 2012. IUCN red list categories and criteria: version 3.1. Ed. 2. Gland, Switzerland and Cambridge, U. K.: IUCN.

Josephson, J. 2000. Going, going, gone? Plant species extinction in the 21st Century. Environmental Science \& Technology 34: 130A-135A.

Justesen, P. T. 1922. Morphological and biological notes on Rafflesia flowers observed in the highlands of mid-Sumatra. Annales du Jardin Botanique de Buitenzorg 32: 64-87.

Kopelman, N. M., J. Mayzel, M. Jakobsson, N. A. Rosenberg, and I. Mayrose. 2015. CLUMPAK: A program for identifying clustering modes and packaging population structure inferences across $\mathrm{K}$. Molecular Ecology Resources 15: 1179-1191.

Kuijt, J. 1969. The biology of parasitic flowering plants. Berkeley and Los Angeles: University of California Press.

Laurance, W. F., D. Carolina Useche, L. P. Shoo, S. K. Herzog, M. Kessler, F. Escobar, G. Brehm, J. C. Axmacher, I. C. Chen, L. A. Gámez, P. Hietz, K. Fiedler, T. Pyrcz, J. Wolf, C. L. Merkord, C. Cardelus, A. R. Marshall, C. Ah-Peng, G. H. Aplet, M. del Coro Arizmendi, W. J. Baker, J. Barone, C. A. Brühl, R. W. Bussmann, D. Cicuzza, G. Eilu, M. E. Favila, A. Hemp, C. Hemp, J. Homeier, J. Hurtado, J. Jankowski, G. Kattán, J. Kluge, T. Krömer, D. C. Lees, M. Lehnert, J. T. Longino, J. Lovett, P. H. Martin, B. D. Patterson, R. G. Pearson, K. S. H. Peh, B. Richardson, M. Richardson, M. J. Samways, F. Senbeta, T. B. Smith, T. M. A. Utteridge, J. E. Watkins, R. Wilson, S. E. Williams, and C. D. Thomas. 2011. Global warming, elevational ranges and the vulnerability of tropical biota. Biological Conservation 144: 548-557.

Lengyel, S., A. D. Gove, A. M. Latimer, J. D. Majer, and R. R. Dunn. 2009. Ants sow the seeds of global diversification in flowering plants. PLoS One 4: e5480.

Lengyel, S., A. D. Gove, A. M. Latimer, J. D. Majer, and R. R. Dunn. 2010. Convergent evolution of seed dispersal by ants, and phylogeny and biogeography in flowering plants: A global survey. Perspectives in Plant Ecology, Evolution and Systematics 12: 43-55.

Madulid, D. A. and E. M. G. Agoo. 2008. (2007). On the identity of Rafflesia manillana Teschem. (Rafflesiaceae). Philippine Scientist 44: 57-70.

Madulid, D. A., I. E. Buot, and E. M. G. Agoo. 2008. (2007). Rafflesia panchoana (Rafflesiaceae), a new species from Luzon island, Philippines. Acta Manilana 55: 43-47.

Marvier, M. A. and D. L. Smith. 1997. Conservation implications of host use for rare parasitic plants. Conservation Biology 11: 839-848.

Medrano, M. and C. M. Herrera. 2008. Geographical structuring of genetic diversity across the whole distribution range of Narcissus longispathus, a habitat-specialist, Mediterranean narrow endemic. Annals of Botany 102: 183-194.

Mittermeier, R. A., N. Myers, J. B. Thomsen, G. A. Da Fonseca, and S. Olivieri. 1998. Biodiversity hotspots and major tropical wilderness areas: Approaches to setting conservation priorities. Conservation Biology 12: 516-520.

Meijer, W. 1997. Rafflesiaceae. Flora Malesiana Ser. I 13: 1-42.

Molina, J. E., K. M. Hazzouri, D. L. Nickrent, M. Geisler, R. S. Meyer, M. M. Pentony, J. M. Flowers, P. B. Pelser, J. F. Barcelona, S. A. Inovejas, I. Uy, W. Yuan, O. Wilkins, C.-I. Michel, S. LockLear, G. P. Concepcion, and M. D. Purugganan. 2014. Possible loss of the chloroplast genome in the parasitic flowering plant Rafflesia lagascae (Rafflesiaceae). Molecular Biology and Evolution 31: 793-803.

Nais, J. 2001. Rafflesia of the world. Kota Kinabalu: Sabah Parks.
Narum, S. R. 2006. Beyond Bonferroni: Less conservative analyses for conservation genetics. Conservation Genetics 7: 783-787.

Nickrent, D. L., A. Blarer, Y.-L. Qiu, R. Vidal-Russell, and F. Anderson. 2004 Phylogenetic inference in Rafflesiales: The influence of rate heterogeneity and horizontal gene transfer. BMC Evolutionary Biology 4: 40.

Nikolov, L. A., P. Endress, M. Sugumaran, S. Sasirat, S. Vessabutr, E. M. Kramer, and C. C. Davis. 2013. Developmental origins of the world's largest flowers, Rafflesiaceae. Proceedings of the National Academy of Sciences USA 110: 18578-18583.

Nybom, H. 2004. Comparison of different nuclear DNA markers for estimating intraspecific genetic diversity in plants. Molecular Ecology 13: 1143-1155.

Olah, L. 1960. Cytological and morphological investigations in Rafflesia arnoldi R.Br. Bulletin of the Torrey Botanical Club 87: 406-416.

Ong, P. S., L. E. Afuang, and R. Rosell-Ambal. 2002. Philippine biodiversity conservation priorities: a second iteration of the national biodiversity strategy and action plan. Quezon City Philippines: DENR-Protected Areas and Wildlife Bureau, CI-Philippines, UP CIDS and FPE.

Peakall, R. and P. E. Smouse. 2012. GenAlEx 6.5: Genetic analysis in Excel. Population genetic software for teaching and research-An update. Bioinformatics 28: 2537-2539.

Pelser, P. B., J. F. Barcelona, and D. L. Nickrent (eds.). 2011. onwards. Co's Digital Flora of the Philippines. www.philippineplants.org.

Pelser, P. B., D. L. Nickrent, and J. F. Barcelona. 2016. Untangling a vine and its parasite: Host specificity of Philippine Rafflesia (Rafflesiaceae). Taxon 65: 739-758.

Pelser, P. B., D. L. Nickrent, J. R. C. Callado, and J. F. Barcelona. 2013. Mt. Banahaw reveals: The resurrection and neotypification of the name Rafflesia lagascae (Rafflesiaceae) and clues to the dispersal of Rafflesia seeds. Phytotaxa 131: 35-40.

Pritchard, J. K., M. Stephens, and P. Donnelly. 2000. Inference of population structure using multilocus genotype data. Genetics 155: 945-959.

Ramamoorthy, R., E. E.-K. Phua, S.-H. Lim, H. T.-W. Tan, and P. P. Kumar. 2013. Identification and characterization of RcMADS1, an AGL24 ortholog from the holoparasitic plant Rafflesia cantleyi Solms-Laubach (Rafflesiaceae). PLoS One 8: e67243.

Raymond, M. and F. Rousset. 1995. GENEPOP (version 1.2): Population genetics software for exact tests and ecumenicism. The Journal of Heredity 86: 248-249.

Renner, S. and J. Feil. 1993. Pollinators of tropical dioecious angiosperms. American Journal of Botany 80: 1100-1107.

Renner, S. and R. E. Ricklefs. 1995. Dioecy and its correlates in the flowering plants. American Journal of Botany 82: 596-606.

Rozen, S. and H. Skaletsky. 1999. Primer3 on the WWW for general users and for biologist programmers. Pp. 365-386 in Methods in molecular biology 132: Bioinformatics methods and protocols, eds. S. Misener and S. A. Krawetz. Totowa, New Jersey: Humana Press.

Sandner, T. M. and D. Matthies. 2017. Interactions of inbreeding and stress by poor host quality in a root hemiparasite. Annals of Botany 119: 143-150.

Schmidt, K. and K. Jensen. 2000. Genetic structure and AFLP variation of remnant populations in the rare plant Pedicularis palustris (Scrophulariaceae) and its relation to population size and reproductive components. American Journal of Botany 87: 678-689.

Schönrogge, K., B. Barr, J. C. Wardlaw, E. Napper, M. G. Gardner, J. Breen, G. W. Elmes, and J. A. Thomas. 2002. When rare species become endangered: Cryptic speciation in myrmecophilous hoverflies. Biological Journal of the Linnean Society. Linnean Society of London 75: 291-300.

Shepherd, K. A., K. R. Thiele, J. Sampson, D. Coates, and M. Byrne. 2015. A rare, new species of Atriplex (Chenopodiaceae) comprising two genetically distinct but morphologically cryptic populations in arid Western Australia: implications for taxonomy and conservation. Australian Systematic Botany 28: 234-245.

Stanton, S., O. Honnay, H. Jacquemyn, and I. Roldán-Ruiz. 2009. A comparison of the population genetic structure of parasitic Viscum album from two landscapes differing in degree of fragmentation. Plant Systematics and Evolution 281: 161-169.

Teijsmann, J. E. 1856. Nadere bijdrage tot de kennis van de voortteling van Rafflesia arnoldii R.Br. in 's Lands Plantentuin te Buitenzorg. Natuurkundig Tijdschrift voor Nederlands Indië 12: 277-281.

Teschemacher, J. E. 1844. On a new species of Rafflesia from Manilla. Boston Journal of Natural History 4: 63-66.

Thiers, B. 2017. [continuously updated]. Index Herbariorum: a global directory of public herbaria and associated staff. New York Botanical Garden's Virtual Herbarium. http://sweetgum.nybg.org/science/ih/. 
Van Oosterhout, C., W. F. Hutchinson, D. P. M. Wills, and P. Shipley. 2004. Micro-checker: Software for identifying and correcting genotyping errors in microsatellite data. Molecular Ecology Notes 4: 535-538.

Wicaksono, A., S. Mursidawati, L. A. Sukamto, and J. A. Teixeira da Silva. 2016. Rafflesia spp.: Propagation and conservation. Planta 244: 289-296.

Williams, E. W., R. Cheung, C. Siegel, M. Howards, J. Fant, and K. Havens 2016. Persistence of the gypsophile Lepidospartum burgessii (Asteraceae) through clonal growth and limited gene flow. Conservation Genetics 17: 1201-1211.

Xi, Z., R. Bradley, K. Wurdack, K. M. Wong, M. Sugumaran, K. Bomblies, J. Rest, and C. C. Davis. 2012. Horizontal transfer of expressed genes in a parasitic flowering plant. BMC Genomics 13: 227.

Xi, Z., Y. Wang, R. K. Bradley, M. Sugumaran, C. J. Marx, J. S. Rest, and C. C. Davis. 2013. Massive mitochondrial gene transfer in a parasitic flowering plant clade. PLOS Genetics 9: e1003265.
APPENDIX 1. Voucher information. Herbarium acronyms follow Thiers (2017).

R. lagascae: Aurora Memorial Natural Park, Aurora Prov., J.R. Callado 382 (CANU, PNH); Bolos Point, Cagayan Prov., J.F. Barcelona 3600 with J. Payba, R. Echanique E Tabuc (CAHUP, SIU); Burgos, Nueva Ecija Prov., J.F. Barcelona 4081 (PNH); Maria Aurora, Aurora Prov., J.F. Barcelona 4033 (PNH); Mt. Banahaw, Quezon Prov., J.F. Barcelona 3819 with P.B. Pelser (CANU); Mt. Irid, Quezon Prov., J.F. Barcelona 3657 with Joel Sarmiento (CAHUP, SIU); Mt. Labo. Camarines Norte/Camarines Sur Prov., J.F. Barcelona 3849 with P.B. Pelser (CANU, PNH); Mt. Makiling, Laguna Prov., J.F. Barcelona 3648 with D.L. Nickrent, E. Malinao \& R. Breva (CAHUP, SIU); Mt. Malinao, Camarines Sur Prov., J.F. Barcelona 4046 (CANU); Mt. Mingan, Aurora Prov., J.F. Barcelona 3867 with P.B. Pelser (PNH); Mt. Natib, Bataan Prov., F. Barcelona 3563 with L.L. Co (CAHUP, SIU); Salazar, Nueva Ecija Prov., J.F. Barcelona 4055 (PNH). R. manillana: Basey, Samar Prov., J.F. Barcelona 3734 et al. (CANU, PNH). 